\author{
Myrosława LENDEL \\ Użhorodzki Uniwersytet Narodowy \\ mlendel@bagel.com.ua
}

\title{
Switłana BUŁA
}

Lwowski Uniwersytet Narodowy im. Iwana Franki

svitlanabyla@mail.ru

\section{SAMORZĄD LOKALNY NA UKRAINIE: FORMA, KTÓRA NIE STAŁA SIĘ TREŚCIĄ}

\section{ABSTRACT Local government in Ukraine: the form without content}

Ukrainian crisis of 2013/2014 that is perceived as Euromaidan can be explained, besides other external reasons, also in the terms of the mental and societal conflict between formally democratic, but non-working legal norms, and the clientele, even feudal political practice. The ideal of democracy can be tested on the local level where the government structures are physically closer to citizens that can use the mechanisms of the direct and other forms of democracy. But in Ukraine the scenario of the rapid and radical transition towards the principles of the local democracy that was implemented in some Central-European countries was not realized because of the inherited system of the centralized governance, the administrative and territorial division, lack of the motivated elite, non-activist type of the political culture. The existing legal environment for functioning of the elected councils and mayors did not stimulated the efficient development of the local communities, as well as the faith of the citizens in the role of the political decision-making, that is the core of the local democracy. Set of the political discourses that are vital in the modern Ukraine and connected with the question of the political system renovation is centered around the decentralization of power, construction of the new scheme of the administrative division of Ukrainian regions. The adoption of the new Constitution in the pair with the political activism of Ukrainian can be a starting point for the construction of the vital local government filled with the sense of democracy. 
Keywords: decentralization, local democracy, local government, Ukraine

Słowa kluczowe: decentralizacja, demokracja lokalna, samorząd lokalny, Ukraina

F enomen zimowego Majdanu przełomu roku 2013 i 2014 na Ukrainie, oprócz innych powodów, można wyjaśnić mentalnym odrzuceniem przez obywateli narastającej przepaści między formalnie istniejącymi instytucjami demokratycznymi a klientelistyczną czy nawet feudalną praktyką rządzenia. Na poziomie społeczności, w których ramach każdy mieszkaniec działa jako „człowiek polityczny”, „istota publiczna”, realizująca prócz prywatnych interesów - niekiedy nawet nie uświadamiając sobie tego także publiczne interesy, współdziałając na płaszczyźnie fizycznego kontaktu z legitymistycznymi strukturami władzy, ten dysonans jest najbardziej rażący. Brak równowagi między „papierowymi” normami prawnymi i realną praktyką rządzenia niewątpliwie wpływa na poziom demokratyczności kultury politycznej. Jej głównymi wyznacznikami są powszechność różnych form uczestnictwa politycznego, szczególnie w głównych segmentach społeczeństwa, przyjęcie w charakterze tradycji i kultury zasad ludowej kontroli i równości politycznej, wiara obywateli w zdolność systemu politycznego do reagowania na najważniejsze wyzwania społeczne ${ }^{1}$.

Należy zauważyć, że zgodnie z tzw. „minimalistycznym”, schumpeterowskim określeniem demokracji jest to forma rządów, w której obywatele mają możliwość wpływania na władzę poprzez wykorzystanie wyborczej konkurencji sił politycznych: jej główne kryteria to elektoralna konkurencja oraz uczestnictwo ${ }^{2}$. Model liberalny, który jest bardziej popularny, przewiduje również kontrolę obywateli nad władzą, ochronę praw mniejszości, istnienie rozmaitych pozapartyjnych i pozawyborczych kanałów - bezpośrednich i pośrednich - realizowania interesów obywateli, ich polityczne równouprawnienie. Ponieważ pojęcie demokracji przedstawicielskiej, dominujące w podobnym dyskursie, $\mathrm{z}$ instytucjonalnego punktu widzenia związane jest $\mathrm{z}$ koncepcją narodu-państwa, to na poziomie lokalnym musi być rozpatrywane w połączeniu z koncepcją demokracji bezpośredniej, będącej zjawiskiem organicznym właśnie w lokalnych społecznościach. Najbardziej udanym podejściem do interpretacji istoty tego zjawiska jest koncepcja demokracji deliberatywnej, spopularyzowana przez J. Habermasa jako optymalny wariant uzgadniania interesów istniejących w społeczeństwie ${ }^{3}$.

Rodzi się pokusa dla badaczy, by dokonywać analizy lokalnego procesu politycznego wyłącznie przez pryzmat funkcjonowania instytucji samorządu lokalnego, którego ukształtowanie i działalność określona jest w prawodawstwie każdego państwa,

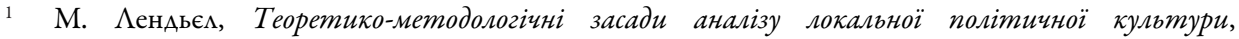
„Політичний менеАжмент” 2008, nr 5, s. 11-22.

2 Й. Шумпетер, Капитализм, социализм и демократия, Москва 1995.

3 Н. Бусова, Делиберативная модель демократии и политика интересов, „Вопросы фикософии” 2002, nr 5, s. 44-54; Ю. Габермас, Структурні перетворення у сфері відкритості. Аослідження категорї̈ громадянське суспільство, przeł. А. Онишко, Аьвів 2000. 
jednakże takie podejście usuwa z pola widzenia procesy niebędące bezpośrednio wyznaczane przez działalność „w ratuszu i wokół niego”. Na przełomie XX i XXI w. przyjęło się rozpatrywać samorząd lokalny, oprócz jego wymiaru prawnego i socjetalnego, także jako zjawisko ze sfery polityki i władzy, a dokładniej jako formę władzy publicznej - władzę municypalną, która jest prawowitym wyrazem samoorganizacji miejscowych wspólnot.

Dla określenia lokalnego reżimu politycznego, zorganizowanego na zasadach uczestnictwa, kontroli, z przejrzystością włącznie, celowe jest wykorzystywanie terminu „demokracja lokalna”, oznaczającego system rozporządzania władzą w społecznościach terytorialnych, którego charakterystycznymi oznakami są autonomia instytucji samorządu lokalnego w stosunku do innych ośrodków władzy publicznej, stosowanie form demokracji przedstawicielskiej i bezpośredniej, konkurencja miejscowych elit politycznych i ich liderów, uczestnictwo obywateli w polityce, uwarunkowane demokratycznymi orientacjami polityczno-kulturalnymi. Lokalna demokracja może być również rozpatrywana jako instrument konsolidowania demokracji w skali ogólnonarodowej, ponieważ rozwiązując problemy komunalne, obywatele nabierają kompetencji, a czując potencjał wpływu na kształtowanie polityki lokalnej, zaczynają popierać system polityczny kraju, w ten sposób go legitymizując ${ }^{4}$.

Z kolei kryzys polityczny przełomu 2013 i 2014 r. potwierdził słuszność tezy filozofa M. Mychalczenki mówiącej o reformach ekonomicznych i politycznych na Ukrainie: każda z nich jest możliwa tylko $w$ tym przypadku, jeżeli miata miejsce już inna zmiana, to znaczy determinuja one siebie nawzajem i wystepuja jako wtasny warunek konieczny ${ }^{5}$. Tak więc jako aksjomat rozpatrujemy zależność kształtowania realnego, nie imitacyjnego, samorządu lokalnego od wywalczonych radykalnych reform politycznych na Ukrainie oraz w drugą stronę: zależność ich zdolności do życia od stworzenia kanałów wpływu obywateli na władze lokalne. Na początku XXI stulecia jednym z głównych kryteriów oceny demokracji jest poziom decentralizacji, którego widocznym przejawem jest kształtowanie sieci nowych prawowitych nosicieli władzy publicznej, a mianowicie struktur samorządu lokalnego.

Zgadzamy się z twierdzeniem, że cechą atrybutywną samorządu lokalnego jest ochrona wolności obywateli poprzez udział w lokalnym procesie politycznym. Oczywiste jest, że w niedemokratycznych systemach politycznych obywatele nie mają dostępu do uczestnictwa w procesach podejmowania decyzji czy też kontroli nad ich realizacją i zazwyczaj w ogóle nie są nimi zainteresowani, organy samorządu podporządkowane są przedstawicielom władz państwowych czy tzw. „partii-państwa”, nie działają zasady subsydiarności ani autonomii budżetowej. Przy czym nawet powojenne totalitarno-autorytarne reżimy w Europie - obawiając się wybuchu niezadowolenia społecznego i chcąc zapewnić funkcjonowanie infrastruktury municypalnej i świadczenie usług ad-

4 A. Vetter, Local Political Competence in Europe: A Resource of Legitimacy for Higher Levels of Government?, „International Journal of Public Opinion Research” 2002, Vol. 14, nr 1, s. 3-18, [online] http:// dx.doi.org/10.1093/ijpor/14.1.3.

5 М. Миханьченко, Політична реальність в Україні: трансформащія, модернізащія, револющія?, „Право вибору” 2005, nr 1, s. 13-14. 
ministracyjnych - legitymizowały samorząd lokalny, jednak bez uwzględnienia w nawet minimalnej formie „ducha” demokracji.

Jest zatem pewną prawidłowością, że ważną cechą rozpoczętych pod koniec lat 80 . XX w. przekształceń społeczno-politycznych w regionie Europy Środkowej i Wschodniej była równoczesność przemian na różnych poziomach społeczeństwa - poczynając od krajowego do lokalnego; te ostatnie można scharakteryzować jako „transformacje lokalne". Ponieważ samorząd lokalny jest w pierwszej kolejności instytucją polityczno-prawną, to w krajach, w których jego funkcjonowanie zostało przerwane w czasie lub też gdzie takiej praktyki nie było w ogóle, potrzebne było przejście etapu umocowania w prawie zasad rządów demokratycznych, po czym można dopiero było przejść do ustalenia tej praktyki, rozwoju odpowiednich orientacji kulturowych, czyli do demokracji lokalnej, mającej wszystkie właściwe temu systemowi składowe części strukturalne.

Specyfikę funkcjonowania samorządu lokalnego na Ukrainie trudno pojąć bez historycznej retrospektywy, a zwłaszcza bez analizy form instytucjonalnych - formalnych i nieformalnych - jego istnienia w okresie sowieckim. W drugiej połowie XX stulecia samorząd lokalny działał w formacie miejscowych rad, które de facto i de iure zależne były od partii komunistycznej, zarówno lokalnego, jak i wyższego szczebla. Skutkiem politycznej liberalizacji w Związku Sowieckim, która rozpoczęła się w drugiej połowie lat 80 . XX w., było rozszerzenie poziomu autonomii terytorialnych organów władzy poprzez zainstalowanie cech „realnego” samorządu lokalnego, którego podmiotami stały się niższe publiczne organy władzy na poziomie wsi (osiedla typu miejskiego, miasta), rejonu, obwodu, dzielnicy w mieście .

Praktyczne wcielenie ideologii decentralizacyjnej polegało na ukształtowaniu w większości krajów postsocjalistycznej Europy systemu władzy, którego główną cechą była pewna autonomia miejscowych wspólnot wobec państwa w warunkach zachowania jej struktur na poziomie regionalnym i subregionalnym. Można zgodzić się z poglądem o uniwersalności cech, które były typowe dla procesu instytucjonalizowania się samorządu w regionie Europy Środkowej i Wschodniej:

1) „odrodzenie” prawne, włącznie z zaprowadzaniem procedury demokratycznych wyborów;

2) konstytucyjne umocowanie zasady samorządu;

3) ograniczony poziom autonomii w stosunku do państwa.

Ważne jest przy tym, by już na poziomie teoretycznym wyjaśnić możliwość implementacji funkcjonalnego modelu demokracji lokalnej w społeczeństwach, które są obciążone spuścizną autorytarną oraz korupcyjną praktyką dnia codziennego. Przecież zjawiskiem uniwersalnym jest kryzys legitymizacji demokracji przedstawicielskiej, którego przejawem jest niska frekwencja podczas wyborów, instytucjonalna bezsilność w świadczeniu usług społecznych wysokiej jakości, klientelizm partyjny, kształtowanie się „QuANGO”. Autorzy europejscy proponują znalezienie mechanizmów przezwy-

Про загальні засади місиевого самоврядування і місцевого господарства в СРСР, „ВіАомості З’їзу народних депутатів СРСР” 1990, nr 16, art. 2.

C. Pateman, Participation and Democratic Theory, Cambridge 1976. 
ciężenia kryzysu właśnie na poziomie lokalnym, który może służyć jako laboratorium demokratycznej korekcji w ramach całego społeczeństwa, jako miejsce rekrutacji nowej elity politycznej, bezpiecznik chroniący przed wybuchem konfliktów politycznych na poziomie ogólnokrajowym ${ }^{8}$. Uczeni proponują następujące drogi implementacji filozofii demokracji lokalnej w działających systemach samorządu: 1) doskonalenie mechanizmów demokracji przedstawicielskiej, w szczególności reformowanie systemów wyborczych; 2) poszerzenie reprezentacji za pomocą formowania kanałów uczestnictwa; 3) postrzeganie obywateli jako nabywców usług, które świadczone są przez władzę, co będzie sprzyjało podniesieniu ich jakości; 4) uzupełnienie demokracji przedstawicielskiej jej bezpośrednią formą .

Jednak reakcje na te wyzwania są w krajach Europy Środkowej i Wschodniej odmienne. I tak w Polsce, na Węgrzech, w mniejszym stopniu na Słowacji przekształcenia decentralizacyjne realizowane były na podstawie modelu „skoku w przepaść, czyli szybko i w sposób radykalny. Ukraina przez dłuższy czas umieszczana była na liście społeczeństw bałkańskich i postsowieckich, w których reformy przeprowadzane są „bez pośpiechu”, co jest typowe dla krajów, gdzie upadek ancien regime’u był wydarzeniem niespodziewanym dla obywateli, którzy nie dysponowali odpowiednią kulturą dla przeprowadzenia zmian lokalnych, podczas gdy w centrum władza nadal pozostała w rękach starej elity ${ }^{10}$.

Jest przy tym aksjomatem twierdzenie, że rozbudowa instytucjonalna samorządu lokalnego, pod panowaniem dowolnego politycznego reżimu, zależy od jego ustroju konstytucyjnego, a nawet od krajowego porządku prawnego.

Społeczeństwo ukraińskie jest społeczeństwem, w którym podstawowe ramy prawne funkcjonowania demokracji lokalnej zostały ukształtowane dopiero pod koniec lat 90. XX w., na co wpłynąła kombinacja kilku czynników, wśród których najbardziej znaczący był długotrwały okres nieokreśloności modelu formy rządzenia i ustroju państwowego na poziomie centralnym, co potwierdza fakt przyjęcia Konstytucji dopiero w 1996 r. Czynnikiem niesprzyjającym w procesie kształtowania samorządu lokalnego był egoizm ogólnokrajowych elit, które nie miały zamiaru dzielić się kompetencjami i zasobami z elitami lokalnymi, przejawiając konserwatyzm w kwestii zachowania uprzedniego ustroju administracyjno-terenowego i organizacyjnych form rządzenia.

To przecież na Ukrainie ze względu na egoizm i konserwatyzm elity, która doszła do władzy, a dokładniej mówiąc, pozostała przy władzy na początku lat 90. XX w., kompetencje i zasoby były nadal skoncentrowane w centrum, a późne (dopiero w roku

8 Local Democracy and the Processes of Transformation in East-Central Europe, red. H. Baldersheim i in., Boulder 1996, Urban Policy Challenges.

9 L. Schaap, Institutional Reform of European Local Politics and Its Impact on Local Democracy, Paper Delivered for Delivery at the 2008 Annual Meeting of the American Political Science Association, 28-30 VIII 2008, [online] http://www.allacademic.com/meta/p279974 index.html.

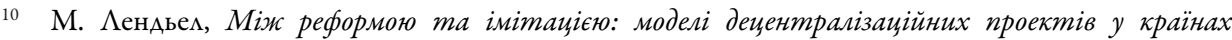
Центральної $і$ Східної Європи, [w:] Інновачійний розвиток суспільства за умов крос-культурних взаємодій. Матеріали міжнародної наукової конференцї, для студентів, аспірантів, науковиів, red. taż, t. 1, Sumy 2008, s. 142-145. 
1997) przyjęcie Ustawy Ukrainy „O samorządzie lokalnym” oznaczało utratę szansy na ukształtowanie w społecznościach gminnych szerokiej warstwy liderów, którzy przejawiliby zainteresowanie i skuteczność w aktywizowaniu obywateli. Nieustrukturyzowanie przestrzeni partyjnej uwarunkowało zmienność norm regulujących system wyborów, z kolei zamknięcie elit wpłynęło na niechęć do tworzenia wyraźnych reguł przeprowadzenia miejscowych referendów.

W przyjętej 28 czerwca 1996 r. Konstytucji Ukrainy zapisanych zostało kilka ważnych zasad funkcjonowania samorządu lokalnego i, ogółem rzecz biorąc, lokalnej władzy publicznej, a mianowicie:

1) uznanie i zagwarantowanie istnienia samorządu lokalnego jako prawa społeczności terytorialnej - mieszkańców wsi, osiedla typu miejskiego, miasta - do samodzielnego decydowania o zagadnieniach o znaczeniu lokalnym $w$ granicach określonych przez Konstytucję i ustawodawstwo Ukrainy;

2) wprowadzenie rzeczywistego samorządu lokalnego na najniższym poziomie, z wykorzystaniem mechanizmów demokracji bezpośredniej i przedstawicielskiej: poprzez rady wiejskie, rady osiedli typu miejskiego, rady miejskie i ich organy wykonawcze;

3) umocowanie dwóch systemów władzy publicznej na obszarze obwodu i rejonu: miejscowej administracji państwowej i samorządu lokalnego ${ }^{11}$.

Pozostałe sformalizowane szczegóły realizacji prawa obywateli do samorządu lokalnego - jak status instytucji samorządu, zakres ich kompetencji (własnych, delegowanych i umownych) czy cechy struktury jego organów i funkcjonariuszy - zostały przewidziane w ustawie o tej samej nazwie, przyjętej 21 maja $1997 \mathrm{r}^{12}$ Dla bazy ustawodawczej, która została uformowana w latach 90. XX w., charakterystyczne są rudymenty sowieckiego typu władzy, m.in. tożsamość funkcji i uprawnień organów różnego szczebla, włącznie z krzyżowaniem się kompetencji miejscowej administracji państwowej i organów samorządu lokalnego, przy niedostatku własnych kompetencji i koniecznych do funkcjonowania środków u tych ostatnich.

Obecny kryzys na wschodzie Ukrainy i ukryta ekspansja Rosji zaktualizowały również dyskusję społeczną na temat ustroju terytorialnego, który został wpisany do Konstytucji Ukrainy jako ustrój unitarny. Są podstawy, by twierdzić, że na Ukrainie przestrzenną organizację władzy charakteryzuje sowiecka spuścizna ustroju administracyjno-terenowego (podział terytorium państwa na obwody, rejony, miasta (różnego znaczenia), osiedla typu miejskiego i miejscowości wiejskie) przy jednoczesnym wprowadzaniu nowego systemu podziału kompetencji pomiędzy różnymi strukturami władzy, które zostały już scharakteryzowane powyżej.

11 Конституціз України, „Відомості Верховної Ради України” 1996, nr 30, art. 141 (ze zm. wprowadzonymi zgodnie z ustawami nr 2222-IV z dnia 8 XII 2004 r., „Відомості Верховної Ради України” 2005, nr 2, art. 44; nr 2952-VI z dnia 1 II 2011 r., „Відомості Верховної Ради України” 2011, nr 10, art. 68; nr 586-VII z dnia 19 IX 2013 r., „Відомості Верховної Ради України” 2014, nr 11, art. 142; nr 742-VII z dnia 21 II 2014 r., „Відомості Верховної Ради України” 2014, nr 11, art. 143).

12 Закон України „Про місцеве самоврядування в Україні”, „Відомості Верховної Ради України” 1997, nr 24. 
Istniejący system ustroju administracyjno-terenowego ma charakter trójpoziomowy:

1) wyższy poziom jednostek terytorialnych stanowią: Autonomiczna Republika Krymu, obwody oraz mające status specjalny miasta Kijów i Sewastopol;

2) poziom średni to rejony i miasta o podporządkowaniu obwodowym;

3) poziom niższy to dzielnice w miastach, miasta o podporządkowaniu rejonowym, osiedla typu miejskiego i wsie.

W skład Ukrainy według stanu na maj 2014 r. (de iure, niezależnie od stanu faktycznego) wchodzą: Autonomiczna Republika Krymu oraz dwadzieścia cztery obwody: dwa miasta o znaczeniu ogólnopaństwowym (Kijów i Sewastopol), 490 rejonów wiejskich; 111 dzielnic w miastach, 460 miast, 885 osiedli miejskiego typu, 1186 osiedli, 27211 wsi.

Zmiany terytorium Ukrainy rozstrzygane są wyłącznie w drodze ogólnoukraińskiego referendum (art. 73 Konstytucji Ukrainy), co w kontekście wspomnianego zagadnienia statusu Krymu oraz „republik terytorialnych”, utworzonych wiosną tego roku w Donbasie, oznacza, że ankiety i badania opinii obywateli Ukrainy w kwestiach autonomii czy też zmiany przynależności państwowej są niekonstytucyjne i nie mogą mieć następstw prawnych.

Tworzenie ram prawnych systemu władzy publicznej na Ukrainie stało się dopiero punktem wyjścia do formowania pola dyskursu w kwestii jej dalszego funkcjonowania, a dokładniej w kwestii współzależności pomiędzy tendencjami centralizacyjnymi i decentralizacyjnymi. W pewnym uproszczeniu dyskusja sprowadzała się do wyboru argumentów pro et contra, a konkretnie w odniesieniu do: najlepszej formuly podziału kompetencji między władzą publiczną i organami samorządu lokalnego, celowości skoncentrowania uprawnień administracyjnych na poziomie lokalnym poprzez połączenie małych gromad, współzależności między efektywnością rządzenia a demokracją ${ }^{13}$.

Inny problem instytucjonalizacji nowego szczebla władzy publicznej na Ukrainie wiązał się z kolizją między praktycznym wcieleniem zasad samorządu i jego normatywno-prawnym umocowaniem. $Z$ formalnego punktu widzenia na Ukrainie została zagwarantowana organizacyjna autonomia samorządu lokalnego na podstawie mieszanego modelu budowy stosunków z państwem. Równocześnie samodzielność miejscowej władzy publicznej, podobnie jak w innych krajach Europy Wschodniej, ograniczona jest przez centralizację finansową, możliwość ingerencji państwa poprzez kontrolę realizowania uprawnień, brak uregulowania sprawy organizacji działalności gromad jako podmiotów samorządności. Aktywność państwa jako podmiotu dominującego, który de iure wyznacza ramy funkcjonowania gromad samorządowych, pozbawiła je równocześnie warunków ekonomicznych niezbędnych do samodzielnego reagowania na wnioski mieszkańców. A przecież na Ukrainie, podobnie jak w większości społeczeństw Europy Środkowej i Wschodniej, w ciągu ostatnich dwóch dziesięcioleci zaszły procesy fragmentacji gromad, zwłaszcza wiejskich, co nie sprzyjało poprawie jakości usług świadczononych ich mieszkańcom.

13 О. Кучабський, Аокальний рівень адміністративно-територіального устрою України: перспективи реорганізачї, „Аемократичне врядування” 2009, nr 3, [online] http://www.lvivacademy.com/visnik3/fail/+Kuchab.pdf. 
Przy tym dyskusję na temat „koncentracji/rozdrobnienia” struktur administracyjno-terenowych można scharakteryzować jako „impulsywny spektakl”, który obchodził przeważnie tylko polityków i poszczególnych ekspertów i nie przyniósł żadnego praktycznego rezultatu, odwracając jednocześnie uwagę od innych wyzwań, jak np. rozszerzenie autonomii finansowej samorządu lokalnego czy możliwości uczestnictwa obywateli.

$\mathrm{Na}$ taki aspekt demokracji lokalnej, jako reprezentacji zbiorowych interesów obywateli w procesie podejmowania decyzji, wpływał niewątpliwie system wyłaniania organów samorządu lokalnego. Oprócz miejscowej rady na Ukrainie obieralne jest stanowisko miejscowego przewodniczącego, który wybierany jest większością względną, co jest charakterystyczne jeszcze tylko dla Armenii i Węgier. Podobnie jak w większości krajów postsowieckich, niezależnie od odmienności norm prawnych i ich koniunkturalnej politycznej celowości, dla wszystkich ich wariantów typowy był przepis o większościowej zasadzie formowania organów przedstawicielskich samorządu w małych gromadach - we wsiach i w osiedlach - i ta norma obowiązuje po dziś dzien ${ }^{14}$.

Najbardziej chyba problematycznym zagadnieniem jest na Ukrainie możliwość wykorzystania form prostego uczestnictwa na poziomie lokalnym, a jest to wszak integralna część składowa systemu demokracji lokalnej. Po przyjęciu w listopadzie 2012 r. nowej Ustawy Ukrainy „O referendum ogólnoukraińskim”, co oznaczało, że przestaje obowiązywać poprzednia ustawa, która regulowała przeprowadzenie również lokalnych wiążących referendów, ta forma demokracji utraciła instrumentarium dla jej zastosowania ${ }^{15}$. W bazowej ustawie o samorządzie lokalnym są przewidziane także inne formy udziału bezpośredniego - walne zgromadzenia obywateli czy inicjatywy miejscowe. Jednakże normy prawne regulujące ich wykorzystanie nie są doskonałe z uwagi na nieokreśloność przedmiotowego pola zastosowania, niewpisanie w statuty gromad, co nie sprzyja realizacji prawa obywateli do uczestnictwa.

Przy tym niedoskonałość czy niekompletność platformy prawnej dla pełnowartościowego funkcjonowania samorządu - w klasycznym rozumieniu - nie była główną przeszkodą w kształtowaniu się systemu demokracji lokalnej. Większe znaczenie miały inne czynniki: charakter reżimu politycznego w skali ogólnokrajowej; niepisane, nieformalne praktyki podejmowania decyzji politycznych; społeczne mechanizmy rozporządzania władzą w terenie; orientacje kulturowe obywateli względem ich własnej roli w polityce. Ukraina w okresie postsocjalistycznym, wraz z częścią krajów bałkańskich, państwami Zakaukazia, Białorusią, Mołdawią i Rosją, należała w latach 1990-2000 do grona państw, dla których charakterystyczna była przewaga elementów niedemokratycznych w systemie politycznym, co zaważyło na metodach sprawowania władzy na szczeblu lokalnym. Interesy dużych partii i elit narodowych były do-

14 Закон України „Про вибори депутатів Верховної Ради Автономної Республіки Крим, місцевих рад та сільських, селищних, міських голів”, „Відомості Верховної Ради України” 2010, nr 35-36.

15 Закон Украйни „Про всеукраїнський референдум”, „Відомості Верховної Ради України” 2013, nr 44-45 . 
datkowym czynnikiem designu lokalnych systemów wyborczych, zakresu uprawnień i środków administracyjnych, które były przekazywane miejscowemu samorządowi. Wszak ich egoizm - jako tych, które nie życzyły sobie dzielić się kompetencjami i zasobami z lokalnymi elitami i przejawiały konserwatyzm w kwestii zachowania uprzednio obowiązującego ustroju administracyjno-terenowego oraz organizacyjnych form rządzenia - był czynnikiem niesprzyjającym nawet w procesie prawnego umocowania samorządu lokalnego. W ciągu dwóch postsocjalistycznych dziesięcioleci realna reforma decentralizacyjna nie została przygotowana, ponieważ na Ukrainie odczuwalny był brak kontrelity, która promowałaby nowe zasady zarządzania publicznego, a także brak odpowiedniego środowiska eksperckiego. Nieustrukturyzowanie się przestrzeni partyjnej zdeterminowało zmienność norm regulujących system wyborów, z kolei zamknięty charakter elit wpłynął na niechęć do tworzenia wyraźnych reguł przeprowadzania lokalnych referendów ${ }^{16}$.

Rolę stymulatora opracowania bazowego ustawodawstwa o samorządzie lokalnym, a także implementacji do jego treści części norm odpowiednich dla systemu demokracji lokalnej odegrała Rada Europy, w szczególności za pośrednictwem Europejskiej Karty Samorządu Lokalnego. Unia Europejska wpływa na normy polityczne i prawne, które regulują zarządzanie publiczne na Ukrainie, za pośrednictwem procesu dostosowywania ustawodawstwa ukraińskiego do europejskiego, co było jednym z priorytetów stosunków bilateralnych w ramach Umowy o partnerstwie i współpracy, Europejskiej Polityki Sąsiedztwa, programów pomocy technicznej, które koncentrowały się na decentralizacji. Jednak o ile w krajach środkowoeuropejskich Rada Europy oraz Unia Europejska wpływały na rozpoczęcie reform, to jednocześnie na obszarze postsowieckim skutkiem ich stymulowania było imitowanie procesu dyfuzji władzy.

Jednym z podstawowych elementów samorządu lokalnego jest demokracja przedstawicielska, której jakość zależy od typu miejscowych elit i liderów, obejmujących stanowiska przedstawicielskie, a dokładniej rzecz biorąc od „wind”, przy których pomocy trafiają oni do struktur władzy. Jak zostało to już udowodnione przez uczonych zajmujących się demokracją lokalną, proces tworzenia elit zależy od wielkości miejscowych społeczności. W małych wspólnotach dla zajęcia niszy lidera ważne znaczenie mają osobiste moralne i administracyjne cechy pretendentów, ich przynależność do sieci społecznych ${ }^{17}$. We wspólnotach typu miejskiego rolę platformy, na której wchodzi się w przestrzeń polityki, odgrywają przeważnie partie czy stowarzyszenia społeczne. W małych społecznościach niższe są poziomy konkurencji elektoralnej oraz odnawiania się elit po każdym wyścigu wyborczym. Na Ukrainie większość przedstawicieli elit urbanistycznych, którzy zdobyli władzę na początku lat 90. XX w., wywodziła się z warstwy nomenklatury i grona sowieckich dyrektorów, w mniejszym stopniu ze środowisk

16 М. Аендьел, Ажерела формування та особливості оновлення місиевих політичних еліт країн Центрально-Східної Європи у постсоиіалістичний період, „Гілея. Науковий вісник” 2009, nr 18, s. 330-346.

17 S. Verba, N. Nie, Participation in America. Political Democracy and Social Equity, New York 1972; M. Keating, Size, Efficiency and Democracy: Consolidation, Fragmentation and Public Choice, [w:] Theories of Urban Politics, red. D. Judge, G. Stoker, H. Wolman, London 1995, s. 117-134. 
opozycji demokratycznej, inteligencji, nowego biznesu. Pod koniec pierwszego postsocjalistycznego dziesięciolecia władza przedstawicielska w miastach zaczęła odnawiać się przy udziale przedsiębiorców, którzy widzieli wspólny interes w przeciwstawianiu się elitom ogólnonarodowym. W małych wiejskich gromadach stanowiska we władzy na początkowym etapie transformacji zostały zajęte przeważnie przez szefów przedsiębiorstw rolnych, których znaczna część cieszyła się wśród obywateli technokratycznym autorytetem i wyrażała pragnienie realizowania potencjału administracyjnego w nowych warunkach. Pod koniec lat 90. XX w. do tego grona oraz lokalnej inteligencji dołączyli również przedstawiciele przedsiębiorców, w tym także starzy działacze gospodarczy. Poza tym w małych społecznościach niższy był poziom konkurencji wyborczej, zaś w dużych zaznaczał się wyższy poziom odnawiania się elit po każdych wyborach. Charakterystyczną cechą było wykorzystanie w ich trakcie środków administracyjnych, co przesądzało o rekrutowaniu elit według oznak zbliżenia się do władzy.

$\mathrm{Na}$ Ukrainie w okresie postsocjalistycznym poziom odnawiania się elit politycznych reprezentowanych w organach samorządu, przynajmniej w miastach, był wysoki, zwłaszcza w pierwszej połowie lat 90. XX w., kiedy w efekcie wyborów ich skład zmienił się w ponad dwóch trzecich. W ciągu następnego dziesięciolecia wskaźnik ten ustabilizował się na poziomie trochę wyższym niż połowa składu, jednak po wprowadzeniu w 2006 r. proporcjonalnych zasad formowania rad miejskich, w takich gromadach odnawianie się elit odbywało się na poziomie $80 \%$. Nie ma zatem jeszcze podstaw, by twierdzić, iż proces tworzenia elit lokalnych na Ukrainie uzyskał stałe cechy, ponieważ znaczącą rolę odgrywają tu czynniki zmienności wyborczego designu, partyjności i wpływów aktorów sceny politycznej operujących na wyższych szczeblach terytorialnych. W małych wspólnotach, podobnie jak w innych społeczeństwach regionu Europy Środkowej i Wschodniej, znaczącymi czynnikami wpływającymi na zajmowanie stanowisk przywódczych są sieci społeczne, a także interesy struktur przedsiębiorców, funkcjonujących na danym terytorium. W obu przypadkach - dużych i małych gromad - dla Ukrainy charakterystyczna jest nieobecność kanałów klasycznej cyrkulacji elit, a także przewaga nieformalnych praktyk w procesie rekrutacji do ich składu.

$\mathrm{Na}$ Ukrainie w ciągu dwóch postsocjalistycznych dziesięcioleci stopniowo rosła rola partii w polityce lokalnej, zwłaszcza w miastach, o czym świadczy wzrost liczby ośrodków partyjnych oraz udział członków partii w składzie organów przedstawicielskich. Tej tendencji sprzyjały czynniki instytucjonalne, w szczególności wprowadzenie w 2006 r. na poziomie miast proporcjonalnego systemu wyłaniania rad. Innowacje wprowadzone do systemu wyborczego w 2010 r., a mianowicie zastąpienie zasady proporcjonalnej w miejskich gromadach ordynacją mieszaną, sprzyjały zwiększeniu szans wyborczych dominujących w regionach sił politycznych, które poparły kandydowanie w okręgach większościowych obdarzonych autorytetem liderów lub wręcz przeciwnie: zaproponowały w charakterze kandydatów w okręgach jednomandatowych reprezentantów partii, dysponujących środkami na przyciągnięcie wyborców.

Wybory municypalne, które odbyły się w październiku 2010 r., zademonstrowały wzrost poparcia i sukces partii pozaparlamentarnych, które posiadały bazę elektoralną ograniczoną do terytorium regionu czy kilku dużych gromad, co także potwierdza 
tendencję właściwą części krajów środkowoeuropejskich. W trakcie tej kampanii popularność zyskała zasada głosowania „przeciwko wszystkim”, co dowiodło rozczarowania obywateli polityką partyjną, nieodzwierciedlającą interesów wspólnot, zwłaszcza po przymusowym upartyjnieniu samorządu. Zgodnie z tendencjami obserwowanymi w innych krajach postsocjalistycznych partie na Ukrainie należą do instytucji, które cieszą się najmniejszym zaufaniem, zwłaszcza w kwestii ich roli w rozwiązywaniu spraw lokalnych.

Jednocześnie format demokracji lokalnej jako istoty samorządu jest możliwy tylko wówczas, kiedy wykorzystują go aktywni i zmotywowani obywatele. Na Ukrainie w latach 1990-2010 poziom wyborczego zaangażowania obywateli się obniżył. Podobnie jak w innych krajach Europy Środkowej i Wschodniej mieszkańcy dużych miast demonstrowali większą gotowość do wystąpienia w obronie swoich praw przed strukturami oficjalnymi, jednakże frekwencja wyborcza była wyższa w miejscowościach wiejskich.

W okresie postsocjalistycznym obywatele biorący udział w dowolnej formie demokracji bezpośredniej stanowili blisko połowę całej aktywnej ludności; na Ukrainie przeprowadzonych zostało również ponad 150 miejscowych referendów. Charakterystyczną cechą zastosowania zinstytucjonalizowanych form demokracji bezpośredniej na Ukrainie - wyborów, referendów, walnych zgromadzeń obywateli, inicjatyw - było manipulowanie ich wynikami przez miejscowe elity. Jak w całym regionie Europy Środkowej i Wschodniej sieci społeczne w małych gromadach stały się podstawą politycznej samoorganizacji.

Ukraina należy do krajów Europy Środkowej i Wschodniej, w których w okresie postsocjalistycznym duża część obywateli zmieniła swoją pozytywną ocenę procesu przechodzenia do demokracji na negatywną (42\%), rozczarowawszy się do jej praktycznego funkcjonowania, co zaważyło na procesie ustanawiania lokalnych systemów władzy. W latach 2005-2010 część obywateli, którzy ufali instytucji samorządu lokalnego, nie przekraczała jednej trzeciej ogółu wszystkich Ukraińców. Jednocześnie mniej więcej połowa respondentów deklarowała swoje zaufanie do miejscowych rad i ich przewodniczących, wskaźnik ten był niższy tylko odnośnie do zaufania do instytucji prezydenta. Jeśli chodzi o ocenę własnej roli politycznej, w 2010 r. około 45\% ludności uważało, że może wpływać na politykę lokalną, i wskaźnik ten był wyższy niż ocena potencjalnego wpływu na ogólnokrajowe procesy polityczne (40\%). Równocześnie dla politycznej orientacji ludności Ukrainy charakterystyczna była specyfika regionalna, a subkultury te były w konflikcie; szczególnie gdy chodziło o zdolność do przeciwstawiania się decyzjom władzy, o ile na obszarze większości kraju wskaźnik ten rósł w okresie postsocjalistycznym, to na wschodzie Ukrainy w tym czasie się obniża1 ${ }^{18}$.

Nie będzie zatem przesadą wyciągnięcie wniosku, że nieadekwatność obserwowanych na Ukrainie form prawnych i realiów procesu politycznego (nieprzejrzystość trybu podejmowania decyzji, brak kanałów dostępu obywateli do polityki, korporatyzacja władzy w określonych jednostkach administracyjno-terenowych, ograniczoność środ-

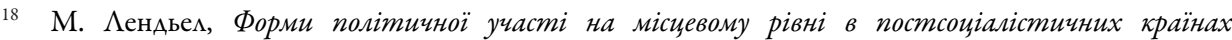
Центральної і Східної Європи, „Нова парадигма: журнал наукових праць” 2009, nr 90, s. 110-125. 
ków, jakimi dysponują publiczne organy władzy, a zarazem korupcja jako decydująca cecha zarządzania) uwarunkowały kryzys na Ukrainie, który rozpoczął się w listopadzie 2013 r. od wstrzymania przez rząd procesu przygotowania do podpisania Umowy stowarzyszeniowej z UE, a w lutym 2014 r. doprowadził do zmiany ustroju konstytucyjnego oraz odsunięcia od władzy znienawidzonego prezydenta W. Janukowycza, rozwijając się w momencie, kiedy to piszemy, w format wojny hybrydowej z Rosją. Jednym z głównych instrumentów przezwyciężenia kryzysu może stać się przyjęcie nowej Konstytucji, i cel ten został już zadeklarowany przez głównych graczy politycznych, z zaprzysiężonym 7 czerwca 2014 r. prezydentem Ukrainy P. Poroszenką włącznie. W'śód głównych płaszczyzn reform znajdują się decentralizacja władzy i zmiana ustroju administracyjno-terytorialnego.

Oczekujemy, że w kontekście prawdopodobnej zmiany Konstytucji Ukrainy zostaną w niej przewidziane normy, które będą sprzyjały realnej decentralizacji uprawnień i środków rządzenia przekazanych do dyspozycji miejscowym społecznościom. To z kolei sprzyjać będzie zmniejszeniu atrakcyjności haseł federalistycznych. Biorąc pod uwagę fakt, że zmiany te powinny skutkować wprowadzeniem zmian do ustawodawstwa, niezbędne jest, aby w perspektywie krótkoterminowej rozpocząć realizację Koncepcji Reformowania Samorządu Lokalnego i Terytorialnej Organizacji Władzy na Ukrainie, która została przyjęta przez rząd na początku kwietnia 2014 r. ${ }^{19}$ To wyzwanie rozpatrywane jest z perspektywy utworzenia przy odpowiednich radach organów wykonawczych, które generalnie rzecz biorąc, przejęłyby właśnie od organów miejscowej (obwodowej i rejonowej) administracji kompetencje w zakresie zarządzania jednostkami terytorialnymi. Jednocześnie celowe byłoby w kontekście opracowania ustawodawstwa o samorządzie lokalnym zachęcanie organów władzy do opracowywania konkretnych przepisów o przeprowadzaniu wysłuchań społecznych, walnych zgromadzeń obywateli czy realizacji inicjatyw lokalnych.

Drugie wyzwanie - przy aksjomatycznym umieszczeniu poza granicami dyskusji scenariusza federalistycznego - polega na realizacji reformy administracyjno-terytorialnej, która nie została zrealizowana w czasach prezydentury W. Juszczenki. Proponowany był wówczas model, przyjęty w Rzeczypospolitej Polskiej, wprowadzenia trzech poziomów terytorialnych - „obwodów - rejonów - gmin”, na każdym z nich funkcjonowałyby organy samorządu lokalnego. Zostały również określone wskaźniki bazowe dla określenia rozmiarów jednostek administracyjno-terytorialnych, co oznaczało zachowanie dotychczasowego podziału regionalnego, jednak z równoczesną konsolidacją w wielu przypadkach miejscowych gromad terytorialnych i rejonów ${ }^{20}$. Ze względu na nieprzygotowanie opinii publicznej reforma ta była przez ludność oceniania negatywnie i dlatego też jej projekt został w ciągu następnych lat zmodyfikowany

19 Розпорядження Кабінету Міністрів України „Про схвалення Конщепџї реформування місиевого самоврядування та територіальної організації влади в Україні" від 1 квітня 2014 р. Nr 333-р, [online] http://zakon4.rada.gov.ua/laws/show/333-2014-\%D1\%80.

20 Р. Безсмертний, Адміністративно-територіальна реформа - реформа для людей, [online] http:// www.kmu.gov.ua/control/uk/publish/article?art_id=19203588\&cat_id=15475285y. 
i zatwierdzony na poziomie konceptualnym w $2009 \mathrm{r}^{21}$, a obecnie planuje się jego wykorzystanie w latach 2014-2017 jako praktycznego instrumentu zmiany terytorialnego ustroju państwa.

Biorąc pod uwagę aktywizację kultury politycznej Ukraińców, ich nieobojętność wobec polityki, z lokalną włącznie, a zatem organiczność wymogów odnośnie do zmiany systemu sprawowania władzy na poziomie gromad terytorialnych, są podstawy, by spodziewać się, że oczekiwana reforma samorządu lokalnego na Ukrainie napełni go wreszcie realnym „duchem” demokracji, w przeciwieństwie do pozornie demokratycznych norm, które były charakterystyczne dla ustawodawstwa przyjętego w latach 90. XX w.

\section{BIBLIOGRAFIA}

Безсмертний Р., Адміністративно-територіальна реформа - реформа для людей, [online] http://www.kmu.gov.ua/control/uk/publish/article?art_id=19203588\&cat_id=15475285y.

Бусова Н., Аелиберативная модель демократии и политика интересов, „Вопросы фимософии" 2002, nr 5.

Габермас Ю., Структурні перетворення у сфері відкритості. Аослідження категорії громадянське суспільство, przeł. А. Онишко,

Закон України „Про вибори депутатів Верховної Ради Автономної Республіки Крим, місцевих рад та сільських, селищних, міських голів”, „Відомості Верховної Ради України” 2010, nr 35-36.

Закон України „Про всеукрайнськийреферендум”, „Відомості Верховної Ради України” 2013, nr 44-45.

Закон України „Промісиеве самоврядування в Україні”, „Відомості Верховної Ради України” 1997, nr 24.

Конституціг України, „Відомості Верховної Ради України” 1996, nr 30, art. 141 (zе zm. wprowadzonymi zgodnie z ustawami nr 2222-IV z dnia 8 XII 2004 r., „Відомості Верховної Ради України” 2005, nr 2, art. 44; nr 2952-VI z dnia 1 II 2011 r., „Відомості Верховної Ради України” 2011, nr 10, art. 68; nr 586-VII z dnia 19 IX 2013 r., „Відомості Верховної Ради України” 2014, nr 11, art. 142; nr 742-VII z dnia 21 II 2014 r., „ВіАомості Верховної Ради України" 2014, nr 11, art. 143).

Конщепщія реформи місиевого самоврядування, [online] http://www.minregionbud.gov.ua/ uk/publish/article/43635.

Кучабський О., Аокальний рівень адміністративно-територіального устрою України: перспективи реорганізації, „Аемократичне врядування” 2009, nr 3, [online] http:// www.lvivacademy.com/visnik3/fail/+Kuchab.pdf.

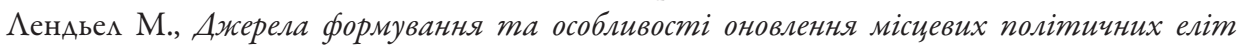
країн Центрально-Східної Європи у постсоиіалістичний період, „Гілея. Науковий вісник" 2009, nr 18.

21 Конщепція реформи місиевого самоврядування, [online] http://www.minregionbud.gov.ua/uk/publish/article/43635. 


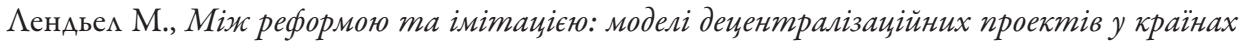
Центральної і Східної Європи, [w:] Інновачійний розвиток суспільства за умов крос-культурних взаємодій. Матеріали міжнародної наукової конференцї, для студентів, аспірантів, науковщів, red. taż, t. 1, Sumy 2008.

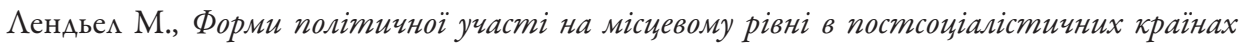
Центральної і Східної Європи, „Нова парадигма: журнац наукових праць” 2009, nr 90.

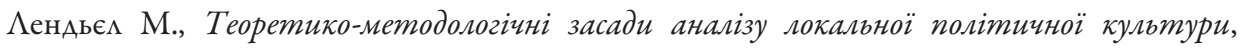
„Політичний менеджмент” 2008, nr 5.

Михальченко М., Політична реальність в Україні: трансформачія, модернізація, револточія?, „Право вибору” 2005, nr 1.

Про загальні засади місиевого самоврядування і місцевого господарства в СРСР, „Відомості 3’ізду народних депутатів СРСР” 1990, nr 16, art. 2.

Розпорядження Кабінету Міністрів України „Про схвалення Концепчї реформування місцевого самоврядування та територіальної організацї влади в Україні" від 1 квітня 2014 p. Nr 333-p, [online] http://zakon4.rada.gov.ua/laws/show/333-2014-\%D1\%80.

Шумпетер Й., Капитализм, социализм и демократия, Москва 1995.

Keating M., Size, Efficiency and Democracy: Consolidation, Fragmentation and Public Choice, [w:] Theories of Urban Politics, red. D. Judge, G. Stoker, H. Wolman, London 1995.

Local Democracy and the Processes of Transformation in East-Central Europe, red. H. Baldersheim i in., Boulder 1996, Urban Policy Challenges.

Pateman C., Participation and Democratic Theory, Cambridge 1976.

Schaap L., Institutional Reform of European Local Politics and Its Impact on Local Democracy, Paper Delivered for Delivery at the 2008 Annual Meeting of the American Political Science Association, 28-30 VIII 2008, [online] http://www.allacademic.com/meta/p279974 index.html.

Verba S., Nie N., Participation in America. Political Democracy and Social Equity, New York 1972.

Vetter A., Local Political Competence in Europe: A Resource of Legitimacy for Higher Levels of Government?, „International Journal of Public Opinion Research” 2002, Vol. 14, nr 1, [online] http://dx.doi.org/10.1093/ijpor/14.1.3.

Ttumaczenie Przemystaw Tomanek

Dr hab. Myrosława LENDEL - kierownik Katedry Politologii i Zarządzania Państwem Użhorodzkiego Uniwersytetu Narodowego (Ukraina).

Dr Switłana BUŁA - doktor nauk politycznych, docent Katedry Politologii Lwowskiego Uniwersytetu Narodowego im. Iwana Franki (Ukraina). 